\title{
A Historical Review of Studies on Japanese Spiders
}

\author{
Takeo YagINUMA \\ Biological Laboratory, Otemon Gakuin, Osaka, Japan
}

Japanese spiders, together with insects, were first studied by Japanese botanists, and some descriptions were made by such botanists as Ekken Kaibara, Ranzan Ono and Rakuho limuro. But it was not till the beginning of the Meiji Era that the current systematic study of Japanese spiders was first taken up by European arachnologists. Taken over by Japanese zoologists in due course of time, their first taxonomic study of Japanese spiders was expanded, and manysided arachnological researches came to be pursued until we find such a great many arachnologists within this country today. In the meantime, there were at times a few setbacks, it is true, but as soon as normalcy was restored after World War II, arachnological researches came back again with fresh force. At present, they are developing into various fields of embryology, experimental morphology and cytology, to say nothing of taxonomy and faunal investigation.

The history of arachnological studies in Japan can be divided into the following five periods:-

1. Ist Period (1877-1912)

From the time the taxonomic study of Japanese spiders was first taken up by European arachnologists till it was taken over by Japanese zoologists.

2. 2nd Period (1913-1935)

The period when this study was continued solely by Japanese, and which formed the foundation of the advancement made in the 3rd period.

3. 3rd Period (1936-1943)

A large number of Japanese arachnologists arrived on the scene, and apart from the taxonomic study of Japanese spiders, many-sided scientific achievements in it were made one after another.

4. 4th Period (1944-1951)

Owing to the strained atmosphere of World War II and the subsequent confusion, scientific studies of any kind were at their low mark and no noteworthy achievements were to be seen.

5. 5th Period (1952- )

Normalcy was restored in people's living and with the resurgence of research 
activities, development is expected in every field of arachnological researches.

\section{Ist Period (the Period of Pioneers)}

It was L. Koch (1877) who first put Japanese spiders on record. By him were described twenty-nine new species and three known species chiefly on the basis of those specimens collected by Albrecht V. Rorctz. Following it, F. Karsch reported fifty-two new species (plus 13 known ones) in 1879 and nine additional ones in 1881 by examining those specimens collected by Hilgendorf and Doenitz mainly in Nagasaki. Descriptions of two more new species were given by $W$. Doenitz in 1881 and out of the specimens collected by Mellottee in Yokohama, six more were reported by E. Simon. In 1894, S. Matsumura listed twenty species found at Atsuta in Hokkaido. This was the first record of its kind ever published by a Japanese. In this record three specific names of Salticidae are given, but as for the rest, only their generic names are listed. What is particularly noteworthy among those listed is the fact that Argyroneta was first described here.

In 1906, "Japanische Spinnen", a voluminous joint work by W. Boesenberg and E. Strand was published, and in it were described 427 species including those already reported by the above-mentioned arachnologists. Most of the specimens employed were collected by W. Doenitz, but some of them were those caught by $T$. Lentz in the central and the northern districts of Japan. All these specimens as well as the related documents and drwings are now placed in the custody of the Museum of Senckenbergische Naturforschende Gesellschaft in Frankfurt. Out of the 427 species, 89 were named by Boesenberg and Strand, 9 species by Strand, and 50 species by Doenitz and Strand. As for the rest, they were species which had already been known or introduced as new additions to the spider fauna of Japan. It is by the publication of this work that the spider fauna of Japan was made fairly clear. If it had not been for this work, therefore, the arachnological studies in Japan would have made no satisfactory progress. The scientific names employed in it were mostly well-considered ones, but because of the imperfection, as well as the immaturity, of the collected specimens, provisional names were also inevitable. Subsequently, E. Strand, therefore, supplemented them with nine specific names in 1907, three in 1909 and two in 1910.

In this period, very few reports were published by Japanese arachnologists except those by $\mathrm{T}$. Okumura and $\mathrm{K}$. Kishinouye. It is not till the following period that they began to rouse themselves into activity. Their only noteworthy achievements are the discovery of trap-door spiders by $K$. Kishinouye (in 1888) and the reports of studies on the development of spiders by the same arachnologist 
(1890-1892). By the latter he laid the foundation of the current embryological study of spiders and the results reported by him in those days are still highly appreciated by the arachnologists of the present day.

2nd Period (the Period of Independence)

Aside from the supplementary presentation of fifteen new species and some corrections and re-descriptions by E. Strand, the study of spiders was carried on chiefly by Japanese arachnologists. T. Okumura, K. Kishinouye and K. Kishida who assumed more prominence in the latter part of the first period began to draw public attention by their splendid contributions. In parallel with the publication of their research results, the related studies abroad were introduced to this country.

K. Kishida, who stood foremost among the arachnologists of the day concentrated his efforts on the taxonomic and ecological studies of Japanese spiders. The reports issued by him on Heptathela kimurai of primitive shape $(1920 ; 1923)$ aroused keen interest among the arachnologists and raised controversial questions of various kinds. Furthermore, he succeeded in making the revision of many erroneously identified species, genera and families, elucidating the habits of many spiders and naming a number of species. The serial publication of his findings in the "Kagaku Sekai" or "World of Science" (1913; 1914) became the only reliable taxonomic records of spiders by a Japanese zoologist. Besides, he published a fairly large number of reports in the Zoological Magazine, the Annotationes Zoologicae Japonenses, the Hakubutsugaku-Zasshi, the Hakubutsu-no-tomo, the Lansania and the Acta Arachnologica. Until the birth of the "Toa Kumo Gakkai" or the "Arachnological Society of East Asia" in 1936, he had been the leading figure in the arachnological research field of this country, and his achievements were indeed great and epochmaking. Under his guidance there came on the scene many arachnologists who were to display noteworthy activities in the following period. In spite of its importance, his report on Yamia watasei KISHIDA, 1920 (Avicularidae) which was found to be of a new species and also a new genus was overlooked by A. Petrunkevitch (1928), C. Fr. Roewer (1942) and P. Bonnet (1959), which is a matter for profound regret. The report "Dwellings of Trap-door Spiders" is likewise a very noteworthy document as an all-inclusive ecological study of Protothelae.

In 1929, a zoological society called the Lansanian Society centering on arachnology was formed, and several arachnologists led by $K$. Kishida published a large number of reports in the "Lansania", the organ of the society. The following reports are the important ones published in this magazine. 
Kishida, E.-A new scheme of classification of spider families and genera, Lansania, $2-13,1930$, pp. 33-43

.......... -Geographical distribution of spider families. Lansania, 2-15, 1930, pp. $65-68$

.......... -A key to the spider families, Lansania, 2-18, 1930, pp. 115-123.
…..... -Synopsis of the spider family Gnaphosidae, Lansania, 4-31, 1932, pp.
$3-14$

The above-mentioned "A New Scheme of Classification" is still supported by most Japanese arachnologists, as it is an excellent classification system based upon his profound taxonomic knowledge. The "Lansania" likewise met with a favorable reception as the sole arachnological magazine among those interested in arachnological studies, but subsequent to the issue of Vol. 3, No. 21, its publication became irregular and has been left in that condition until today, much to the regret of arachnologists. Today the back numbers of the magazine are precious and hard to obtain.

In 1931, Seiji Yuhara's "Kumo-no-Kenkyu" or "Study of Spiders" was posthumously published by the friends of the deceased, and as many as 176 species were illustrated in it. Most of these species were those collected in Wakayama prefecture, the rest consisting of very remarkable specimens found elsewhere. As a fairly comprehensive work on arachnology, this was the first of its kind, and formed a valuable arachnological guide which could supply nearly all the needed information of all the common species found in this country. Viewed from the current level of arachnology, the book undeniably contains some mistakes but there is little doubt that this has done much toward developing arachnological research activities. Moreover this book contains descriptions of some species, which could be considered original.

After 1932, the fauna of spiders both in the northern districts of Japan and in Formosa was gradually brought to light chiefly by S. Saito. Through him many additions new to the fauna of spiders in Japan and a fairly large number of new species became known and the number of species increased remarkably. In Saghalien, following the descriptions of seven species in 1932, twenty-seven more (including 2 new species) were supplemented in 1934 and nineteen more ( 3 new species) in 1935. Together with the three species reported by Kishida in 1924, forty-seven species in all were made known in Saghalien. Spiders in the Kurile Islands were also described by $S$. Saito: thirteen (including 5 new species) in 1932, twenty-four ( 5 new species) in 1933 and six in 1935. On both islands of 
Rishiri and Rebun, eleven ( 2 new species) were recorded. Formosan spiders were partly brought to light in 1933 when forty-three (17 new species) were put on record. These were further supplemented with ten more ( 2 new species) in 1936.

In 1934, eighty-three (including 22 new species) in Hokkaido were also described by Saito and the spider fauna in this vast province was made pretty clear. These arachnological discoveries in these hitherto unexplored areas revealed that the fauna in the northern districts of Japan and that in Europe and Siberia had a considerable number of species in common, and the revelation led to the fresh discussion of the Hatta's line and the Blakiston's line from the zoogeographical viewpoint. What was particularly noteworthy was the fact that from their geographical position, the Kurile Islands had, in mixed existence, species both of the Palaearctic and the Nearctic region. All the research results stated above became very important data for making zoogeographical studies in this country.

In 1936, S. Komatsu's "Iconographia Aranearum" Vol. 1 was brought out, but the illustrations in it were mainly rough sketches based on those in the Japanische Spinnen, a joint work by Boesenberg and Strand. Besides, the book contained no descriptions that should accompany these pictures. Considering, that it was what might be called a de luxe edition in those days, it was rather poor in contents, but the scientific and Japanese names found in it and also the appendix are of some help. In the same year of 1936, K. Kishida likewise published a book called Idiobiologia Aranearum and containing collected photos of spiders. Although limited in its contents, it is a work of importance in arachnological literature.

\section{3rd Period (the Period of Development)}

The year 1936 was an epochal year in the history of arachnology. With $\mathrm{T}$. Fukui as President, the Arachnological Society of East Asia was founded by those interested in arachnology, and T. Esaki, K. Kishida, S. Saito, H. Takashima and $T$. Uyemura figured largely as leaders in pushing on the activities of this sole academic society for arachnological researches. With the establishment of this society, rapid strides were made in the arachnological studies in this country, with the result that many and varied brilliant research results were obtained. The "Acta Arachnologica", its organ, drew the keen attention of many arachnologists in the world, and notable reports were published in it year after year. During World War II, the "Acta Arachnologica" was on the decline for a time, but making its brilliant come-back after the war, it is in a fair way to still further development today. T. Uyemura has been the central figure of the research activities since the establishment of this society, and under his assistance 


\section{(44)}

and guidance, many excellent arachnologists have appeared in various parts of the country as well as among those under his direct instruction. In consequence of their activities, notable developments were made in both fields of taxonomy and ecology. The spiders of Japan were for the most part brought to light, with each regional spider fauna clarified, the new species duly described and their habits closely investigated.

In 1938 and 1941, S. Saito published two volumes in the "Fauna Nipponica" and in them he dealt with as many as 227 species. These two volumes were the summing up of all the related reports published up to that time, and great importance, therefore, was attached to them as an all-inclusive and exhaustive companion, indispensable to any student of arachnology. In view of the great expecta. tions entertained and the warm reception they met with, it is a pity, however, that no succeeding volumes were published. Even today there is a strong demand in many quarters that these two volumes should be supplemented and brought to completion. In $1937, \mathrm{~S}$. Saito again put on record 123 species (including 21 new ones) of Tohoku region (the northernmost part of the Main Island) and clarified the hitherto not too well-known distribution of spiders in this region. It is especially noteworthy that a species belonging to Palpimanidae was added to the fauna of Japan in this book.

In the same year, M. Yoshikura brought out a volume on Argiopidae of Sag* halien, making clear the habits of Argiopidae and giving detailed descriptions. This resulted in the addition of ten more species to the Argiopidae of Saghalien. It is regrettable, however, that many beautiful pictures in natural colours were printed in monochrome as a result of the defective condition of printing in those wartime days.

In 1941, Y. Chikuni completed his "Spiders of the Japan Alps", in which he dealt with 132 species, giving their detailed descriptions and their pictures. The work had its merit in revealing not only the spiders of this mountainous country but also their vertical distribution.

In 1943, Y. Hosono published his "Life of Spiders". His keen observation and skillful style of writing made this book both entertaining and informative. It is considered to be one of the important ecological studies of spiders in Japan.

In 1943, I. Kayashima brought out his "Spiders of Formosa", dealing with 50 species. Many of these species are to be found in Japan, too, and it served to some extent as a reference-book.

K. Nakatsudi, who directed his attention to the hitherto neglected peripheral 
areas of Japan, discovered 81 species (including 2 new ones) on Izu-shichito or the Seven Isles of Izu in 1942, and 22 species ( 2 new ones) in Amami and Okinawa in 1943. The discoveries were regarded as important materials for the study of distribution. Although much had been expected of him as a promising taxonomist, he died during World War II, and his death is still lamented by many arachnologists who used to know him.

The research achievements during this $3 \mathrm{rd}$ period are exceptionally many and varied, but those worthy of particular mention are K. Kishida's taxonomic studies, T. Uyemura's taxonomic and ecological studies and establishment of the Araneus cornutus line, T. Komatsu's numerous ecological observations and K. Sekiguchi's research into the life history of Heteropoda venatoria, which were all published in Acta Arachnologica.

\section{4 th Period (the Period of Stagnation)}

Toward the last stage of World War II, normalcy was completely disrupted either by mobilization or by evacuation or by forced change of research themes, and the arachnological studies in this country reached their lowest mark. During this period no noticeable reports were published till as late as 1951 . Under such crucial circumstances, however, the "Acta Arachnologica", the organ of the Arachnological Society of East Asia, kept up its publication through the unstinted endeavour of $\mathrm{H}$. Takashima. It is a feature of this period that Myriapoda replaced Arachnida, which had receded more and more into the background.

\section{5 th Period (the Period of Resurgence)}

The post-war confusion was restored to normalcy and the arachnological studies made their resurgence. Fresh developments were seen again in all the fields of arachnology as well as in both fields of taxonomy and ecology.

Between 1950 and 1952, S. Suzuki made cytological studies on spiders, thereby opening up a hitherto unexplored research-field. By him the respective karyotypes of about 60 species were revealed and the consequent discussion of the evolution and classification of spiders supplied important data for the conversion from arti. ficial to natural classification. The identification of species based on karyotypes may, of course, be difficult, but they are undeniably an important key to the clas. sification of genera or higher categories.

From 1952 to 1958, M. Yoshikura pursued embryological studies on Heptathela kimurai KISHIDA and Atypus karschi DoENITz, and the developmental processes of primitive spiders were greatly clarified. These studies were the first of the 
kind after Kishinouye's researches on Lycosa and Agelena and supplied important data for the discussion of phylogeny. His new finding about the respiratory organ of male spiders of Heptathela kimurai (1954) is also worthy of note.

Between 1952 and 1954, K. Sekiguchi ascertained from the point of experimental morphology the production of double embryos in the development of spiders by centrifugation, and thus succeeded in disclosing their developmental processes. Both his examination of the spinning organ of Argiopidae (1955) and his discov* ery of a new spinning gland or glandula flagelliformis (1952) were of great sig. nificance, likewise.

In 1956 T. Yaginuma published a photo book entitled "In the World of Spiders" and containing the ecological pictures of spiders of about 100 species. In 1959 S. Saito brought out "The Spider Book Illustrated in Colours" dealing with the spiders centering around those found chiefly in the northern part of Japan. The appearance of this book is expected to contribute greatly toward future development of arachnology in this country where there had been few or no spider books in such a graphic form before.

T. Yaginuma devoted himself to the task of identifying the specimens collected in various places and initiating beginners into the research technique of arachnology on the one hand, while on the other he reexamined the hitherto employed scientific names both on the basis of the Rules of the Zoological Nomenclature and from the taxonomical point of view. Besides correcting the erroneously identified families, genera and species of Japanese spiders, he thus endeavoured to clarify the spider fauna of Japan and place Japanese spiders in their right generic positions. All his research results were reported in the Atypus, the Acta Arachnologica and other journals. Of these reports, the more important ones were re-edited and contained in his "Spiders of Japan in Colour" issued in 1960. All the research results obtained by him in the past, whether published or unpublished, are collectively dealt with in his "Revision of the Families and Genera of Japanese Spiders" (in Japanese). Ryoji Oi's recent study "Linyphiid spiders of Japan" (1960) is worthy of special mention here. By his re-examination of those spiders belonging to Linyphiidae and Micryphantidae to which little attention was paid in the past, much taxonomic information has been obtained, with the result that many new species have now been described.

The conspicuous trend of this fifth period is the appearance in large numbers of young and energetic arachnologists who at the present time are engaged in their active research-work in various fields of arachnology. For one thing, the 
establishment of the Kansai Branch of the Arachnological Society of East Asia in 1952 and the removal to Osaka of its Headquarters in 1954 can be considered to have lent an impetus to fresh interest in research activities. For another, the "Atypus", the supplementary organ of the Arachnological Society came to be issued in parallel with the "Acta Arachnologica" and more opportunities of publishing their research results have thus been made more easily available to many students of arachnology, arousing still greater interest in their researchwork.

Mention must also be made of those investigations into each regional spider fauna conducted not by individuals as in the past but by museums of natural history, research institutes for natural resources, universities and colleges on a large scale and in areas hitherto unexplored arachnologically. The museums of natural history in such places as Yamaguchi Pref., Hiwa-cho (Hiroshima Pref.) and Osaka City have recently done much in their hunt for local spider specimens, and put quite a lot of them on display. As its museum extension work, the Osaka Museum of Natural History has often sent out experts to distant places and out. lying islands to make inquiries into each local fauna. In 1958, the Research Institute for Natural Resources organized a scientific expedition to investigate the Shimokita Peninsula and collected about three hundred spiders which were handed to the writer for identification. The writer, on examination, found seventy two species (including 3 new ones) and the specimens became good research data for comparison with those in Hokkaido in discussing the value of the Blakiston's Line.

The speleological investigations started by both Kyoto University and the Speleological Society of Japan deserves attention, too. The spider specimens obtained by such investigations are taken charge of by the present writer, and it is considered that they will be useful as important materials for the discussion as to how far isolation and geological changes have affected the evolutional processes of spiders. Furthermore, the feature of more recent times is that agricultural experimental stations have come to take up the study of spiders from the standpoint of regarding them as natural enemies to noxious insects and utilizing them for the extermination of these insects. The fact that the supposed usefulness of spiders has now been scientifically confirmed is perhaps a good development. In this connection the Tokushima Agricultural Experimental Station did an especially excellent investigatory work. In the field of forestry as in that of agriculture, attention is now paid to the usefulness of spiders. I. Kayashima discovered the 
utility value of Lynx spiders (Oxyopes sertatus $\mathrm{L}$. $\mathrm{KoCH}$ ) for the extermination of cryptomerian leaf-fies (Contarinia inoueyi MANI), and this method of extermination is expected to come into use before long.

In conclusion, the Japanese arachnologists (partaking in the study of spiders) at present and their research fields are shown below.

Abbreviations :

T. (Taxonomy),

E. (Ecology), Em. (Embryology),

C. (Cytology),

M. (Morphology), Ap. (Applied arachnology).

Zg. (Zoogeography)

Tamao Fuxur, Yokohama.-President of Arachnological Soc. of East Asia.; Izumi Kayashima, Miyazaki Pref., Kyushu.-T. \& Ap. ; Kyukichi Kishida, Tokyo. -T.E. \& Zg.; Toshihiro Komatsu, Nagano Pref.-E. \& Cave spiders.; Yasunori MiyosI, Matsuyama, Ehime Pref.-T. (Opiliones \& Myriapoda); Kuniyasu MORIKaWA, Matsuyama, Ehime Pref.-T. (Pseudoscorpionida); Kiyoshi NAKahIRA, Kochi Pref. -E. ; Ryoji OI, Osaka.-T. : Chiyoko OKuma, Fukuoka.-T.E. ; Saburo SAITo, Hakodate Hokkaido.-T.; Koichi SEKIGUCHI, Tokyo.-Em.M.T.E.; Seisho SuzukI, Hiroshima. -T.C. (Opiliones); Haruo TAKashima, Tokyo.-T. (Scorpionida); Toshio Uyemura, Tokyo.-T.E. ; Takeo Yaginuma, Osaka.-T.E. ; Makoto YoshiKURA, Kumamoto.-Em.

後記 原稿は少ないながら Variety に富み，何れも充奏した内容で17巻2号をまと めることが出来ましたずい分早くから原稿をいただいていた方には中訳りなく思って いますが，創立25周年に当り，ATYPUS の記念号之共に本誌も発行出来たととを喜び ます、ACTAにももっとくだけたものをとの声すありますが，経済面さえ豊かになれ ばいつでも夷現出来るごとです、どうか今後共御支援の程をお䫝いします．（Y)

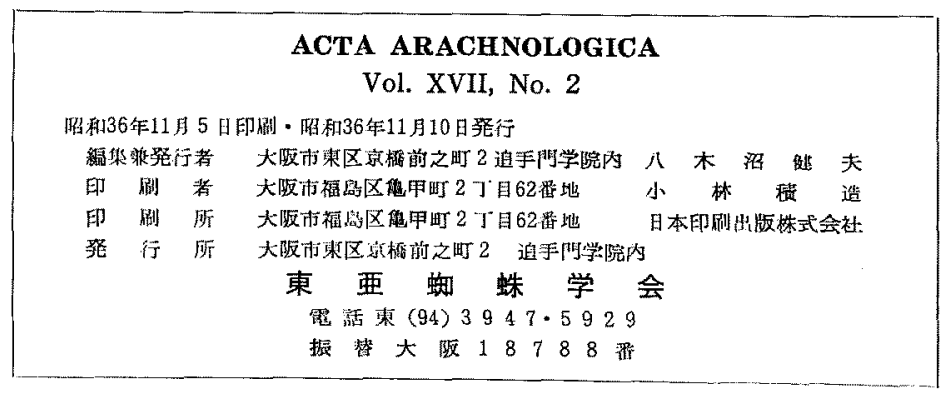

